\title{
HNF1B Genetic Testing In a Turkish Cypriot Population with a High Incidence of Familial Kidney Disease
}

\author{
Rhian L Clissold ${ }^{1,2^{*}}$, D Deren Oygar ${ }^{3}$, Daniel P Gale ${ }^{4}$, Coralie Bingham ${ }^{2}$ and Guy H Neild ${ }^{3}$ \\ ${ }^{1}$ University of Exeter Medical School, RILD Level 3, Barrack Road, Exeter, Devon, EX2 5DW, UK \\ ${ }^{2}$ Exeter Kidney Unit, Royal Devon and Exeter Hospital, Barrack Road, Exeter, Devon, EX2 5DW, UK \\ ${ }^{3}$ Nephrology Department, Nicosia State Hospital, Nicosia, North Cyprus \\ ${ }^{4}$ UCL Centre for Nephrology, Royal Free Campus, London, NW3 2PF, UK
}

Keywords: Kidney disease; Cyprus; Nephropathy; HNF1B

\section{Short Communication}

Kidney disease is common in Cyprus, particularly familial kidney disease [1]. Most patients with familial disease have one of two clinical phenotypes, either (i) haematuric nephropathy with persistent microscopic haematuria, late-onset proteinuria and variable renal failure; or (ii) asymptomatic renal impairment in the absence of dipstick positive haematuria and proteinuria. Work from Deltas et al. has shown that for those with autosomal dominant haematuric nephropathy, mutations in the COL4A3/COL4A4 genes of type IV collagen or CFHR5 are often found $[2,3]$ and those where renal disease co-segregates with a normal urinalysis typically have autosomal dominant MUC1-associated tubulointerstitial kidney disease (formerly termed medullary cystic kidney disease type 1) [4]. Familial microscopic haematuria is caused by heterozygous COL $4 A 3 / C O L 4 A 4$ mutations in approximately $40 \%$ of cases, suggesting that additional and still unknown genes are likely to be responsible for a similar phenotype [5]. Therefore, work is currently underway to investigate the Turkish Cypriot population for monogenic causes of these different phenotypes.

In this population, cystic kidney disease is also common. In pedigrees with COL4A3/COL4A4 mutations, multiple small and large renal cysts were found in an unusually large number of patients in four of the 11 families [6]. $40 \%$ of patients with autosomal dominant MUC1-associated tubulointerstitial kidney disease had evidence of renal cysts on ultrasound, as well as $27 \%$ of unaffected individuals [4]. Heterozygous mutations of the $H N F 1 B$ gene are the commonest known monogenic cause of developmental kidney disease and renal cysts are the predominant renal phenotype [7]. HNF1B-associated disease is considered a multi-system disorder (Table 1) and early-onset diabetes mellitus is the most frequent extra-renal phenotype seen. The mean age at diagnosis of diabetes is 24 years [8], although this can range from the neonatal period [9] to late middle age [10]. Genetic changes comprise whole-gene deletions in approximately $50 \%$ of patients and base substitutions or small insertions/deletions within the HNF1B gene in the remainder [7]. Following the incidental finding of a missense mutation in HNF1B (G76C) in an elderly Cypriot male with multicystic kidneys, we aimed to perform $H N F 1 B$ genetic testing in 11 individuals from the Turkish Cypriot population with renal cysts and diabetes plus a family history of either renal disease or diabetes.

Patients from the Turkish Cypriot community were recruited from outpatient clinics in north Cyprus. Inclusion criteria included the presence of unexplained renal disease with diabetes and a family history of renal disease (unexplained renal impairment or cysts) and/ or diabetes in at least one first degree relative. Informed written consent was obtained from all participants and the study was conducted in agreement with the Declaration of Helsinki Principles. Basic clinical information was collected and blood samples were taken for DNA extraction. Mutation screening of $H N F 1 B$ was performed by sequencing of coding exons and exon-intron boundaries together with gene dosage assessment by multiplex ligation-dependent probe amplification as previously described [10,11]. Glomerular filtration rate (GFR) was estimated using the simplified Modification of Diet in Renal Disease formula in adults [12]. GFR was set at 0 for patients on renal replacement therapy.

11 unrelated patients participated in the study (Table 2); 8/11 were males and the median age was 65 years (interquartile range

\begin{tabular}{|c|c|}
\hline Organ & Phenotype \\
\hline Kidney & $\begin{array}{l}\text { - Developmental kidney disease } \\
\text { - } \text { Bilateral hyperechogenic kidneys on prenatal } \\
\text { - Renal cysts } \\
\text { - Single kidney } \\
\text { - Renal hypoplasia } \\
\text { - Other: horseshoe and duplex kidneys, collecting system } \\
\text { abnormalities, bilateral hydronephrosis } \\
\text { Electrolyte abnormalities } \\
\text { - Hypomagnesaemia } \\
\text { - Hyperuricaemia (and early-onset gout) }\end{array}$ \\
\hline Pancreas & $\begin{array}{l}\text { Early-onset diabetes mellitus } \\
\text { Pancreatic hypoplasia } \\
\text { - Hypoplasia of body and tail of pancreas with slightly } \\
\text { atrophic head } \\
\text { - Pancreatic exocrine dysfunction, which is often subclinical }\end{array}$ \\
\hline Genital tract & $\begin{array}{l}\text { Genital tract malformations } \\
\text { - } \quad \text { Bicornuate uterus } \\
\text { - } \quad \text { Rterus didelphys } \\
\text { - } \\
\text { - } \quad \text { Double vaginal aplana } \\
\text { - }\end{array}$ \\
\hline Liver & $\begin{array}{l}\text { Abnormal liver function } \\
\text { - Asymptomatic rise in the levels of liver enzymes (common) } \\
\text { - Neonatal cholestasis (rare) }\end{array}$ \\
\hline Brain $^{*}$ & $\begin{array}{l}\text { Neurodevelopmental disorders } \\
\text { - Autism spectrum disorders } \\
\text { - Cognitive impairment }\end{array}$ \\
\hline
\end{tabular}

*Only in patients with an $H N F 1 B$ whole-gene deletion occurring in the context of a larger $17 \mathrm{q} 12$ microdeletion

Table 1: Clinical features seen in HNF1B-associated disease.

*Corresponding author: Rhian L Clissold, University of Exeter Medical School, Exeter Kidney Unit, Royal Devon and Exeter Hospital, Barrack Road, Exeter, Devon, EX2 5DW, UK, Tel: 01392 406366; Fax: 01392 402527; E-mail: rhian. clissold@nhs.net

Received: February 04, 2016; Accepted: February 12, 2016; Published: February 19, 2016

Citation: Clissold RL, Oygar DD, Gale DP, Bingham C, Neild GH (2016) HNF1B Genetic Testing In a Turkish Cypriot Population with a High Incidence of Familial Kidney Disease. J Nephrol Ther 6: 235. doi:10.4172/2161-0959.1000235

Copyright: @ 2016 Clissold RL, et al. This is an open-access article distributed under the terms of the Creative Commons Attribution License, which permits unrestricted use, distribution, and reproduction in any medium, provided the original author and source are credited. 
Citation: Clissold RL, Oygar DD, Gale DP, Bingham C, Neild GH (2016) HNF1B Genetic Testing In a Turkish Cypriot Population with a High Incidence of Familial Kidney Disease. J Nephrol Ther 6: 235. doi:10.4172/2161-0959.1000235

Page 2 of 3

[IQR] 62-73.5). All patients had been diagnosed with renal cysts (although imaging was inconclusive in three cases) and the median age at diagnosis of renal disease was 60 years (IQR 55-60). 6/11 patients had end-stage renal disease and were established on haemodialysis; estimated GFR ranged from $15-90 \mathrm{ml} / \mathrm{min} / 1.73 \mathrm{~m}^{2}$ in the remainder. Diabetes was present in all patients (possible diagnosis in one case only); the age at diagnosis ranged from 40-60 years. Both sequencing and dosage analysis of the $H N F 1 B$ gene were normal in all 11 patients.

No HNF1B gene mutations or deletions were identified in this series of 11 individuals from the Turkish Cypriot community with renal cysts and diabetes. The family history of renal disease or diabetes in first degree relatives is suggestive of a monogenic aetiology so it is likely that other causative genes remain to be found. The detection rate of HNF1B-associated renal disease ranges from $10-24 \%$ in study cohorts including adults of $\geq 50$ individuals where both mutation and deletion screening of $H N F 1 B$ was performed $[10,11,13,14]$. However, the adult participants in these studies tended to be younger and of either a White European or Asian background so the findings may not be relevant to this cohort of older patients from a Turkish Cypriot population.

Several limitations were associated with this work. The sample size was small so the absence of $H N F 1 B$ gene anomalies in this group may have been due to chance alone. The clinical information available for patients was often very limited and the older age of participants meant an increased likelihood of more common pathologies, such as simple renal cysts and type 2 diabetes. $H N F 1 B$ genetic testing was limited to a specific phenotype of renal cysts and diabetes; however, both the renal and extra-renal phenotype of HNF1B-associated disease is very variable so it may have been useful to study patients with a wider range of clinical features.

The increasing use of next generation sequencing, which enables sequencing of the entire human genome within several days, will be useful in this Turkish Cypriot community where there is a high incidence of familial kidney disease. New information from Cyprus on the genetic basis of renal disease will have a major impact on the identification of causes of renal impairment in neighbouring countries, where the aetiology is often unknown and the economic conditions do not allow for universal health care [15].

In summary, no $H N F 1 B$ gene mutations or deletions were identified in a small cohort of 11 patients with renal cysts and diabetes from the Turkish Cypriot population where there is a high incidence of familial renal disease; this highlights the importance of continued investigation for novel genetic causes in this community.

\section{Disclosure}

The authors declare no competing interests.

\section{Acknowledgements}

$\mathrm{R}$ Clissold is supported by a Medical Research Council Clinical Training

\begin{tabular}{|c|c|c|c|c|c|c|c|c|c|}
\hline \multirow[b]{2}{*}{ Patient } & \multirow[b]{2}{*}{ Sex } & \multirow[b]{2}{*}{$\begin{array}{l}\text { Current age } \\
\text { (years) }\end{array}$} & \multirow[b]{2}{*}{ Renal phenotype } & \multirow{2}{*}{$\begin{array}{c}\text { Age at } \\
\text { detection of } \\
\text { renal disease } \\
\left(\text { years) }{ }^{1}\right.\end{array}$} & \multirow[b]{2}{*}{$\begin{array}{c}\text { eGFR } \\
\left(\mathrm{ml} / \mathrm{min} / 1.73 \mathrm{~m}^{2}\right)^{2}\end{array}$} & \multirow[b]{2}{*}{$\begin{array}{l}\text { Diabetes } \\
\text { phenotype }\end{array}$} & \multirow[b]{2}{*}{$\begin{array}{l}\text { Other phenotypic } \\
\text { information }\end{array}$} & \multicolumn{2}{|c|}{ Family history $^{3}$} \\
\hline & & & & & & & & $\begin{array}{c}\text { Renal } \\
\text { disease }\end{array}$ & Diabetes \\
\hline 1 & $\mathrm{M}$ & 65 & $\begin{array}{l}\text { Renal cysts \& low- } \\
\text { grade proteinuria }\end{array}$ & 55 & 40 & $\begin{array}{l}\text { DM detected at } \\
\text { age } 50\end{array}$ & & - & + \\
\hline 2 & $\mathrm{M}$ & 64 & Renal cysts & 55 & 15 & $\begin{array}{l}\text { DM detected at } \\
\text { age } 50\end{array}$ & & + & + \\
\hline 3 & $\mathrm{~F}$ & 48 & $\begin{array}{c}\text { Renal cysts \& } \\
\text { stone disease } \\
\text { with low-grade } \\
\text { proteinuria \& } \\
\text { microscopic } \\
\text { haematuria }\end{array}$ & & 90 & $\begin{array}{l}\text { DM detected at } \\
\text { age } 40 \text {; treatment } \\
\text { with metformin }\end{array}$ & & + & + \\
\hline 4 & $\mathrm{M}$ & 74 & $\begin{array}{c}\text { Renal cysts } \\
\text { \& asymmetric } \\
\text { kidneys with ESRD }\end{array}$ & 60 & 0 & DM & & + & - \\
\hline 5 & M & 76 & $\begin{array}{l}\text { Renal cysts \& } \\
\text { ESRD }\end{array}$ & 60 & 0 & $\begin{array}{l}\text { DM detected at } \\
\text { age } 60\end{array}$ & & + & + \\
\hline 6 & $\mathrm{M}$ & 73 & Renal cysts & 60 & 47 & $\begin{array}{l}\text { DM detected at } \\
\text { age } 60\end{array}$ & & + & + \\
\hline 7 & M & 53 & $\begin{array}{l}\text { Possible renal } \\
\text { cysts \& ESRD }\end{array}$ & 40 & 0 & DM & & + & - \\
\hline 8 & $\mathrm{~F}$ & 60 & $\begin{array}{l}\text { Possible renal } \\
\text { cysts \& ESRD }\end{array}$ & 45 & 0 & DM & $\begin{array}{c}\text { Learning difficulties, } \\
\text { short stature \& } \\
\text { obesity }\end{array}$ & + & - \\
\hline 9 & $\mathrm{M}$ & 77 & $\begin{array}{l}\text { Renal cysts \& } \\
\text { ESRD }\end{array}$ & 60 & 0 & DM & & + & - \\
\hline 10 & $\mathrm{M}$ & 65 & $\begin{array}{c}\text { Renal cysts \& } \\
\text { small left kidney } \\
\text { with low-grade } \\
\text { proteinuria \& } \\
\text { microscopic } \\
\text { haematuria } \\
\end{array}$ & 60 & 63 & $\begin{array}{l}\text { DM detected at } \\
\text { age } 47\end{array}$ & & + & + \\
\hline 11 & $\mathrm{~F}$ & 69 & $\begin{array}{l}\text { Possible renal } \\
\text { cysts \& ESRD }\end{array}$ & & 0 & Possible DM & & + & - \\
\hline
\end{tabular}

${ }^{1}$ Blank field denotes unknown information; ${ }^{2}$ eGFR recorded as 0 if patient has ESRD; ${ }^{3}$ Family history was recorded as present $(+)$ or absent $(-)$ depending on whether a first-degree relative was affected with renal disease or diabetes. Abbreviations: DM, diabetes mellitus; eGFR, estimated glomerular filtration rate; ESRD, end-stage renal disease; F, female; $M$, male

Table 2: Clinical features of the 11 study participants. 
Citation: Clissold RL, Oygar DD, Gale DP, Bingham C, Neild GH (2016) HNF1B Genetic Testing In a Turkish Cypriot Population with a High Incidence of Familial Kidney Disease. J Nephrol Ther 6: 235. doi:10.4172/2161-0959.1000235

Fellowship. This work was partly funded by the Rosetrees Trust, St Peter's Trust and an Impulsion Grant from the European Renal Association.

\section{References}

1. Connor TM, Oygar DD, Gale DP, Steenkamp R, Nitsch D, et al. (2013) Incidence of end-stage renal disease in the Turkish-Cypriot population of Northern Cyprus: a population based study. PLoS One 8: e54394.

2. Voskarides K, Damianou L, Neocleous V, Zouvani I, Christodoulidou S, et al. (2007) COL4A3/COL4A4 mutations producing focal segmental glomerulosclerosis and renal failure in thin basement membrane nephropathy. J Am Soc Nephrol 18: 3004-3016.

3. Athanasiou Y, Voskarides K, Gale DP, Damianou L, Patsias C, et al. (2011) Familial C3 glomerulopathy associated with CFHR5 mutations: clinical characteristics of 91 patients in 16 pedigrees. Clin J Am Soc Nephrol 6: 14361446.

4. Stavrou C, Koptides M, Tombazos C, Psara E, Patsias C, et al. (2002) Autosomal-dominant medullary cystic kidney disease type 1: clinical and molecular findings in six large Cypriot families. Kidney Int 62: 1385-1394.

5. Papazachariou L, Demosthenous P, Pieri M, Papagregoriou G, Savva I et al. (2014) Frequency of COL4A3/COL4A4 mutations amongst families segregating glomerular microscopic hematuria and evidence for activation of the unfolded protein response. Focal and segmental glomerulosclerosis is a frequent development during ageing. PLoS One 9: e115015.

6. Pierides A, Voskarides $\mathrm{K}$, Athanasiou $\mathrm{Y}$, loannou $\mathrm{K}$, Damianou $\mathrm{L}$, et al (2009) Clinico-pathological correlations in 127 patients in 11 large pedigrees, segregating one of three heterozygous mutations in the COL4A3/ COL4A4 genes associated with familial haematuria and significant late progression to proteinuria and chronic kidney disease from focal segmental glomerulosclerosis. Nephrol Dial Transplant 24: 2721-2729.
7. Clissold RL, Hamilton AJ, Hattersley AT, Ellard S, Bingham C (2015) HNF1Bassociated renal and extra-renal disease-an expanding clinical spectrum. Nat Rev Nephrol 11: 102-112

8. Chen YZ, Gao Q, Zhao XZ, Bennett CL, Xiong XS, et al. (2010) Systematic review of TCF2 anomalies in renal cysts and diabetes syndrome/maturity onse diabetes of the young type 5. Chin Med J (Engl) 123: 3326-3333.

9. Edghill EL, Bingham C, Slingerland AS, Minton JA, Noordam C, et al. (2006) Hepatocyte nuclear factor-1 beta mutations cause neonatal diabetes and intrauterine growth retardation: support for a critical role of HNF-1beta in human pancreatic development. Diabet Med 23: 1301-1306.

10. Edghill EL, Bingham C, Ellard S, Hattersley AT (2006) Mutations in hepatocyte nuclear factor-1beta and their related phenotypes. J Med Genet 43: 84-90.

11. Edghill EL, Oram RA, Owens M, Stals KL, Harries LW, et al. (2008) Hepatocyte nuclear factor-1beta gene deletions--a common cause of renal disease. Nephrol Dial Transplant 23: 627-635.

12. Levey AS, Bosch JP, Lewis JB, Greene T, Rogers N, et al. (1999) A more accurate method to estimate glomerular filtration rate from serum creatinine: a new prediction equation. Ann Intern Med 130: 461-470.

13. Heidet L, Decramer S, Pawtowski A, Moriniere V, Bandin F, et al. (2010) Spectrum of HNF1B mutations in a large cohort of patients who harbor renal diseases. Clin J Am Soc Nephrol 5: 1079-1090.

14. Nakayama M, Nozu K, Goto Y, Kamei K, Ito S, et al. (2010) HNF1B alterations associated with congenital anomalies of the kidney and urinary tract. Pediatr Nephrol 25: 1073-1079.

15. Neild GH, Oygar DD, Hmida MB (2011) Can we improve the diagnosis of renal failure? A revised coding system for the Middle East and North Africa. Saudi J Kidney Dis Transpl 22: 651-661. 